\title{
THE EFFECT OF PRICE AND TASTE ON THE PURCHASE
}

\author{
Rahmat Hidayat ${ }^{\star 1}$, Intisari Haryanti ${ }^{2}$ \\ STIE BIMA, Indonesia*12 \\ rahmatthidayat.stiebima16@gmail.com¹, Intisariharyanti@gmail.com²
}

\begin{abstract}
Many business people who open a culinary business as a human need that serves fast food and drinks. Based on the habit of these people who prefer to buy fast food and drinks, it will benefit these business people, one of which is a culinary or restaurant business. Ranging from snacks to heavy food. Consisting of regional food, and even Korean food. Competition between culinary businesses is increasingly high. Aisy Drink is one of the hundreds of culinary businesses that sell fast food and beverages. Many menu choices provided, such as fried rice, noodles, and kebabs. Likewise, the drink, there are many choices of flavors. By carrying out the theme of hospitality, this place is a favorite choice of youth and other circles. However, buyers are increasingly here increasingly quiet. The results of observations by researchers with other similar businesses, the price in Aisy Drink is quite expensive, both food and drinks. The food was pegged at a price above twenty thousand, while the drinks were in the range of fifteen thousand rupiahs. The researcher is interested in researching this matter and the researcher hopes that this research can become an example for other prospective entrepreneurs, especially graduates from STIE Bima.
\end{abstract}

Keywords: Price, Taste, Purchase Decisions

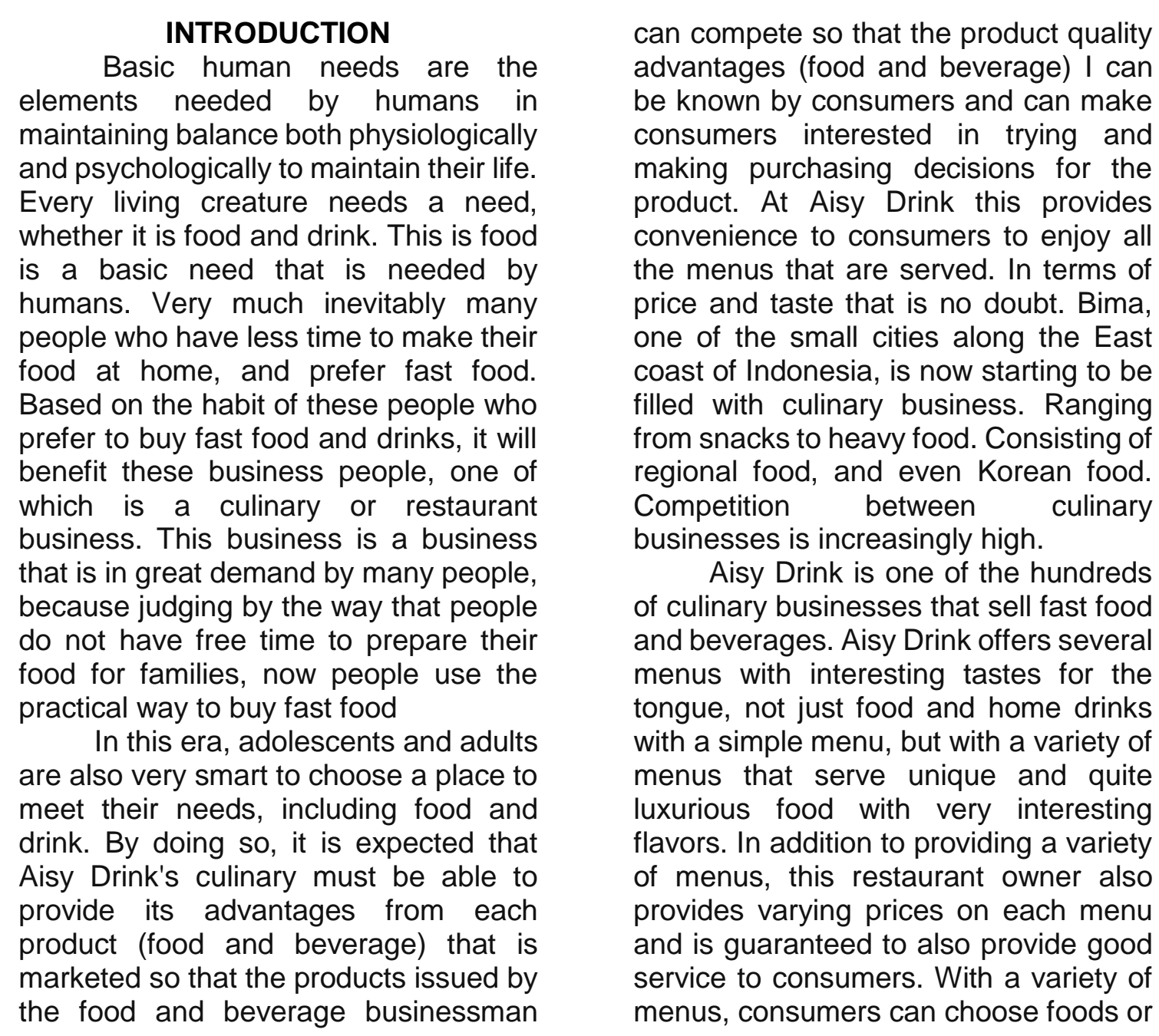

Submitted: July 15, 2020; Revised: July 30, 2020; Accepted: August 06, 2020;

Published: August 11, 2020; Website: http://journalfeb.unla.ac.id/index.php/almana 
drinks that are preferred by consumers. Many menu choices provided, such as fried rice, noodles, even Arabian food, namely kebabs. Likewise, the drink, there are many choices of flavors. By carrying out the theme of hospitality, this place is a favorite choice of youth and other circles. The benefits of this Aisy Drink place can be used as a place to meet with colleagues, socialize, and even to hold a birthday party by providing quality service and facilities that are good enough for potential customers, so that potential customers need not doubt the quality provided by Aisy Drink. The results of observations by researchers with other similar businesses, the price in Aisy Drink is quite expensive, both food and drinks. The food was pegged at a price above twenty thousand, while the drinks were in the range of fifteen thousand rupiahs. What's more interesting is, since the appearance of this Aisy, the buyers are not always as busy as the buyers at the meatball stalls. What's wrong with Bima people's tastes, the researcher is interested in researching this matter and the researcher's hopes that this research can become an example for other prospective entrepreneurs, especially graduates from STIE Bima

Which formulates the problem in this study "Does the price and taste influence the purchasing decisions on Aisy Drink in the City of Bima, both partially and simultaneously?" This study aims to determine the effect of price and taste on purchasing decisions on Aisy Drink in the City of Bima, both partially and simultaneously.

As for this study is to find out the effect of price and taste on purchasing decisions, intended to find out the reason consumers decide to buy Aisy products, as a basis for consideration of Aisy owners to determine prices and make products according to their consumers' tastes. Other goals for prospective entrepreneurs (beginners) in opening business opportunities such as aisy business.
According to Kotler \& Keller (2009) states that price is an element in the marketing mix that not only determines profitability but also as a signal to communicate the proportion of the value of a product. According to Tjiptono \& Chandra (2012) states that price is the only element of the marketing mix that brings income to the organization. So the authors conclude that the price is income from capital and also profits.

Price Indicators: availability of price lists, price matches, competitive prices, and affordability (Romdonah, 2014). The affordability of prices is a Consumers can reach prices set by the company. There are usually several types of products in one brand and the price too different from the cheapest to most expensive. With prices set by many consumers to buy products. 2. Prices according to ability or price competitiveness.

Consumers often compare the price of a product with the product the other. In this case, the expensive price of a product is very cheap considered by consumers when buying the product. 3 . Price compatibility with product quality. Price is often used as an indicator of quality for consumers often choose a higher price between two goods because of them see a difference in quality. If prices are higher people tend to assume that the quality is also better. 4. Price match with benefits. Consumers decide to buy a product if the benefits are felt greater or equal to what has been issued for getting it. If consumers feel the benefits of the product are smaller than money spent then consumers will assume that the product It is expensive and consumers will think twice about doing it repeat purchase

A person's behavior in enjoying everything that is consumed is certain the first to assess the taste of food to be eaten in taste or food quality itself. The high taste makes someone can judge the taste of the meal is suitable for consumption or not. The taste of food is one of the important advantages of establishing a restaurant. Restaurants 
that have quality products with quality flavors high will grow high consumers too.

Njoto (2016) revealed that taste is a way of choosing food that must be distinguished from the taste (taste) of the food. Food taste is very influential on the identity of where the food came from. With indicator characteristics, odor, and the aroma of the taste, consumers can judge that the food consumed has its characteristics in each region. Besides, food sellers must provide a high quality of products (food) that are sold. Three indicators will be used to measure this indicator variable taste, that is: aroma, taste, and texture (Sari, 2013).

According to Suharso \& Yudi (2010) said the purchase decision is the stage where the buyer has made his choice and made a purchase of the product, and consume it. Mutoharoh \& Minarsih (2015) purchasing decisions are a series of processes through which consumers decide on purchasing actions. Haryanti \& nurdin (2019) revealed the purchase decision is an act of the customer in determining the choice of the various alternatives available and deciding to buy. From some of these meanings, the researcher concludes, that the purchasing decision is an act of someone in deciding to purchase the item they selected.

Indicators of Purchasing Decisions: stability of a product, habits in buying products, giving recommendations to others, making repeat purchases (Kotler \& Armstrong, 2011)

\section{METHODS}

This type of research includes associative research. Associative research is a statement that indicates the relationship between two variables (Sugiyono, 2016). The population used is AISY DRINK consumers whose numbers cannot be known (Unknown Population) with a research sample of 50 people Amirullah (2013) with the sampling used is purposive sampling.

The research instrument used a questionnaire/questionnaire containing a series of statements given to respondents to obtain the data needed by using a Likert scale, as well as the data collection techniques used namely, (1) interviews, namely the process of dialogue with resource persons about the problem in detail, (2) questionnaire/questionnaire, which is a list of questions asked to respondents to obtain data and information needed (3) observations, namely data collection through direct observation in the field or location which is the place of research (4) literature study, namely is a research data collection using various types of research assistance such as books, journals, or previous research as a reference in research. Research location of Aisy Drink in Bima, Jl. Datuk Dibanta NO. 1, Pane, West Rasanae, Kota Bima, West Nusa Tenggara. 


\section{RESULTS AND DISCUSSION}

Table 1. Validity Test

\begin{tabular}{ccccc}
\hline Research variable & Statement & R count & R Table & $\begin{array}{c}\text { Invalid } \\
\text { description }\end{array}$ \\
\hline \multirow{4}{*}{ PRICE } & Item 1 & 0,673 & 0,300 & Valid \\
& Item 2 & 0,437 & 0,300 & Valid \\
& Item 3 & 0,690 & 0,300 & Valid \\
& Item 4 & 0,687 & 0,300 & Valid \\
& Item 5 & 0,690 & 0,300 & Valid \\
& Item 6 & 0,639 & 0,300 & Valid \\
& Item 7 & 0,767 & 0,300 & Valid \\
& Item 8 & 0,673 & 0,300 & Valid \\
& Item 1 & 0,677 & 0,300 & Valid \\
& Item 2 & 0,488 & 0,300 & Valid \\
TASTE & Item 3 & 0,627 & 0,300 & Valid \\
& Item 4 & 0,617 & 0,300 & Valid \\
& Item 5 & 0,611 & 0,300 & Valid \\
& Item 6 & 0,713 & 0,300 & Valid \\
& Item 1 & 0,766 & 0,300 & Valid \\
& Item 2 & 0,310 & 0,300 & Valid \\
& Item 3 & 0,516 & 0,300 & Valid \\
PURCHASE & Item 4 & 0,586 & 0,300 & Valid \\
DECISION & Item 5 & 0,749 & 0,300 & Valid \\
& Item 6 & 0,766 & 0,300 & Valid \\
& Item 7 & 0,625 & 0,300 & Valid \\
& Item 8 & 0,547 & 0,300 & Valid \\
\hline
\end{tabular}

Source: Data has been processed by the author (2020)

According to Sugiyono (2016) shows the degree of accuracy between the data that occurs on the object with the data collected by researchers to find the validity of an item, we correlate the score of items with the total of these items. From the table above it appears that all variables are valid

Table 2. Reliability Test

\begin{tabular}{cccc}
\hline Research variable & Cronbach's alpha & Normal limit & Reliable Information \\
& & & \\
\hline PRICE & 0,811 & 0,6 & Reliable \\
TASTE & 0,677 & 0,6 & Reliable \\
PURCHASE DECISION & 0,772 & 0,6 & Reliable \\
\hline
\end{tabular}

Source: Data has been processed by the author (2020)

According to Imam Ghozali (2013) Reliability is related to public trust. Reliability is a tool to measure a list of questionnaire questions that are indicators of the variables studied. A reliability test is performed on question items that are declared valid. The results from the above table state that the list of questions regarding all three variables is reliable. 


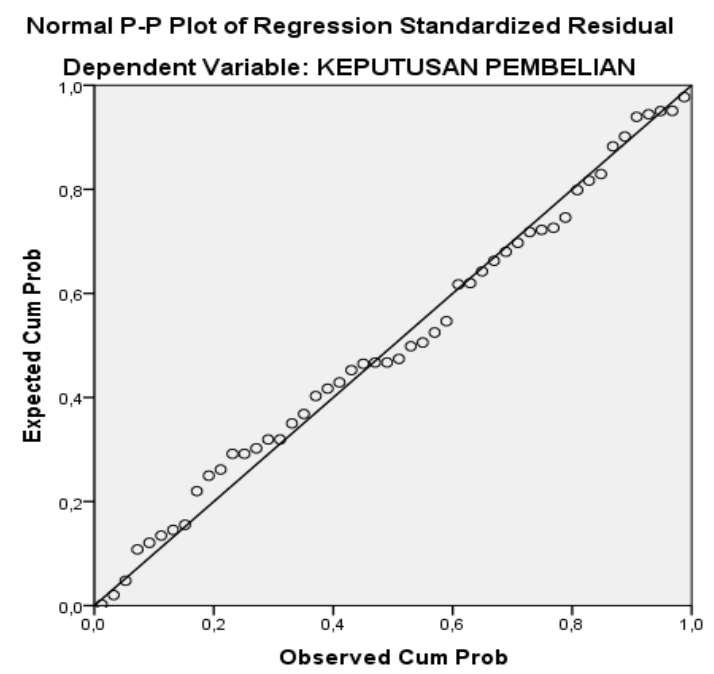

Figure 1. Normality Test

Source: Data has been processed by the author (2020)

From the picture above it can be seen that the research data has a normal distribution and distribution because the data is centered on the average value and the median or PP plot values are located diagonally, so it can be said that the data is normally distributed.

Table 3. Multicollinearity Test Results

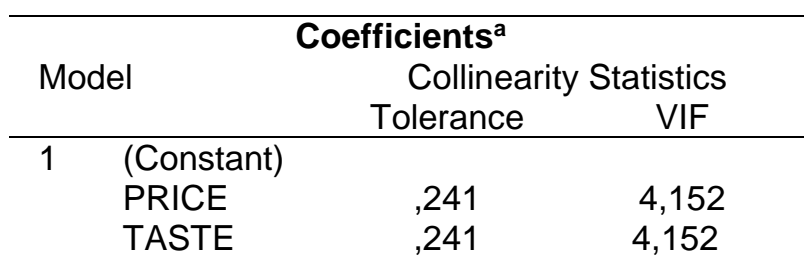

a. Dependent Variable: PURCHASE DECISION

Source: Data has been processed by the author (2020)

The analysis above shows that there are no symptoms of multicollinearity on the research variables. Seeing the tolerance value is more than 0.10 and the VIF value is less than 10 then the variable items are eligible to be used in further testing. This is consistent with Ghozali (2011) in multicollinearity in the regression model or not in the regression model.

Table 4. Heteroscedasticity Test

\begin{tabular}{lcc}
\hline \multicolumn{1}{c}{ Variable } & Sig. & \multicolumn{1}{c}{ Conclusion } \\
\hline Price & 0,061 & Non heteroskedastisitas \\
Taste & 0,018 & Non heteroskedastisitas \\
\hline \multicolumn{2}{l}{ Source: Data has been processed by the author (2020) }
\end{tabular}


From table 4 above it can be seen that the significance value of the price and taste variable is more than 0.05 . Because the significance is more than
0.05 , it can be concluded that there is no heteroscedasticity problem in the regression model.

Table 5. Autocorrelation Test Results

\begin{tabular}{l} 
Model $\begin{array}{c}\text { Model Summary } \\
\text { Change Statistics } \\
\text { df2 }\end{array}$ Sig. F Change \\
\hline $1 \quad$ Durbin-Watson \\
a. Predictors: (Constant), TASTE, PRICE 1,907 \\
b. Dependent Variable: PURCHASE DECISIONS \\
Source: Data has been processed by the author (2020)
\end{tabular}

There is no autocorrelation if the value of $\mathrm{DW}>\mathrm{DU}$ and $(4-\mathrm{DW})>\mathrm{DU}$ or can be denoted as follows: (4-DW)> DU $<$ DW. By looking at the DW value in the table of 1.907 then $4-\mathrm{DW}=1.903>\mathrm{DU}$ of 1.503. Thus it was concluded that there was no autocorrelation in this study.
Multiple regression analysis was chosen to analyze the submission of hypotheses in this study. The test was carried out using the SPSS Version 20 program, as follows:

Table 6. Test Results for Multiple Regression Analysis

\begin{tabular}{|c|c|c|c|c|c|}
\hline \multicolumn{6}{|c|}{ Coefficients $^{\mathrm{a}}$} \\
\hline \multirow[t]{2}{*}{ Model } & \multicolumn{2}{|c|}{ Unstandardized Coefficients } & \multirow{2}{*}{$\begin{array}{l}\text { Standardized } \\
\text { Coefficients } \\
\text { Beta }\end{array}$} & \multirow[t]{2}{*}{$\mathrm{t}$} & \multirow[t]{2}{*}{ Sig. } \\
\hline & B & Std. Error & & & \\
\hline (Constant) & 2,603 & 2,399 & & 1,085 & 284 \\
\hline PRICE & 175 & 135 & 178 & 1,294 & 202 \\
\hline TASTE & ,959 & 181 & ,727 & 5,291 &, 000 \\
\hline
\end{tabular}

Source: Data has been processed by the author (2020)

From the results of the regression analysis it can be seen that the multiple regression equation is as follows:

$$
Y=2,603+0,175 X 1+0,969 X 2
$$

Based on these equations, it can be explained as follows: (1) A constant value of 2.603 can be interpreted if the Price and Taste variable is considered zero, then the Purchase Decision will be 2.603; (2) The beta coefficient value of the variable price of 0.175 means that every change in the price variable (X1) is one unit, it will result in a change in the Purchasing Decision of 0.175 units, with other assumptions that are fixed; (3) The beta coefficient value on the Taste variable is 0.969 , meaning that every change in the Taste variable (X2) is one unit, it will result in a change in the Purchasing Decision of 0.969 units, with other assumptions that are fixed. One unit increase in the Taste variable will increase Purchase Decision by 0.969 units. 
Table 7. Correlation Test Results

\begin{tabular}{ccccc}
\hline $\begin{array}{c}\text { Mode } \\
\text { I }\end{array}$ & $R$ & R Square & $\begin{array}{c}\text { Adjusted } R \\
\text { Square }\end{array}$ & $\begin{array}{c}\text { Std. Error of the } \\
\text { Estimate }\end{array}$ \\
\hline 1 &, $887^{a}$ &, 786 &, 777 & 1,705 \\
\hline \multicolumn{4}{c}{ Source: Data has been processed by the author $(2020)$}
\end{tabular}

Based on the results of the correlation coefficient test table obtained results of 0.887 . When referring from the correlation coefficient table the level of closeness of the relationship between price and taste for purchasing decisions at AISY DRINK is at a very strong relationship. Adjusted $\mathrm{R} 2$ test results in this study obtained a value of 0.786 . This shows that the Purchasing Decision $(\mathrm{Y})$ is influenced by Price (X1) and Taste
(X2) of $78.6 \%$, while the remaining $21.4 \%$ is influenced by other factors not included in this study.

Furthermore, to find out whether the hypothesis proposed in this study was accepted or rejected, the hypothesis test will be carried out using the t-test and the $\mathrm{F}$ test. The results of the hypothesis testing are explained as follows:

Table 8. T-Test Results (Partially)

\begin{tabular}{|c|c|c|c|c|c|}
\hline \multicolumn{6}{|c|}{ Coefficients $^{a}$} \\
\hline \multirow[t]{2}{*}{ Model } & \multicolumn{2}{|c|}{$\begin{array}{l}\text { Unstandardized } \\
\text { Coefficients }\end{array}$} & \multirow{2}{*}{$\begin{array}{c}\text { Standardized } \\
\text { Coefficients } \\
\text { Beta }\end{array}$} & \multirow[t]{2}{*}{$\mathrm{T}$} & \multirow[t]{2}{*}{ Sig. } \\
\hline & B & $\begin{array}{l}\text { Std. } \\
\text { Error }\end{array}$ & & & \\
\hline 1 & 2,603 & 2,399 & & 1,085 & ,284 \\
\hline $\begin{array}{l}\text { (Constant) } \\
\text { PRICE } \\
\text { TASTE } \\
\text { a. Depende }\end{array}$ & $\begin{array}{r}, 175 \\
, 959 \\
\\
\text { le: Purchas }\end{array}$ & $\begin{array}{r}135 \\
, 181\end{array}$ & $\begin{array}{l}178 \\
, 727\end{array}$ & $\begin{array}{l}1,294 \\
5,291\end{array}$ & $\begin{array}{l}\text {,202 } \\
, 000\end{array}$ \\
\hline
\end{tabular}

Source: Data has been processed by the author (2020)

If the value of $t$ count $<t$ table or the value of Sig. > 0.05, then $\mathrm{Ho}$ is accepted. $T$ value calculated from the price of 1.294 and significant 0.202 , it means that the price variable does not affect the purchase decision variable.
While the $t$ value of the taste of 5,291 with a significant 0.00 then it means that there is an influence of taste on purchasing decisions and taste has a partially greater influence on purchasing decisions on aisy drink.

Table 9. F Test Results (Simultaneously)

\begin{tabular}{|c|c|c|c|c|c|}
\hline \multirow{2}{*}{ Model } & \multicolumn{3}{|c|}{ ANOVA $^{a}$} & \multirow[b]{2}{*}{$\mathrm{F}$} & \multirow[b]{2}{*}{ Sig. } \\
\hline & $\begin{array}{l}\text { Sum of } \\
\text { Squares }\end{array}$ & Df & $\begin{array}{l}\text { Mean } \\
\text { Square }\end{array}$ & & \\
\hline 1 & 501,906 & 2 & 250,953 & 86,362 &, $000^{\mathrm{b}}$ \\
\hline Regression & 136,574 & 47 & 2,906 & & \\
\hline Residual & 638,480 & 49 & & & \\
\hline \\
\hline \multicolumn{6}{|c|}{ a. Dependent Variable: Purchase Decisions } \\
\hline \multicolumn{6}{|c|}{ b. Predictors: (Constant), taste, price } \\
\hline
\end{tabular}


From the table above it can be seen that the calculated $F$ value of $86.382>\mathrm{F}$ table of 3.18 and significant at the number 0.00 , it can be concluded that the price and taste table together influence the purchase decision.

The results of the t-test statistics for the Price variable obtained the value of $t$ arithmetic 1,294 with a t-table value of $2,011 \quad(1,295<2,011)$ with $a$ significance value of 0.201 greater than $0.05(0.202<0.05)$, and the regression coefficient has a positive value of 0.178 , the hypothesis that "Price has a positive and significant influence on the Purchase Decision of Aima Drink in Bima City" is rejected.

The results of the t-test statistics for Taste obtained t value of 5.291 with a t-table value of $2.011(5.291<2.011)$ with a significance value of 0.000 less than $0.05 \quad(0.000<0.05)$, and the regression coefficient has a positive value of 0.959 , the hypothesis which states that "Taste has a positive and significant influence on the Purchase Decision of Aima Drink Bima City" is accepted. Allegedly Price and Taste together have a positive and significant influence on the Purchase Decision of Aima Drink in Bima City.

From the test results obtained $F_{\text {count }}$ value of 86.336 with $F_{\text {table }}$ value of $3.19(86.336>3.19)$ with a significance of $0.000(0.000<0.05)$. Because the significance value is less than 0.05 $(0.000<0.05)$, and the coefficient of determination has a positive value of 0.786 , it can be concluded that "Price and Taste together have a positive and significant influence on the Purchase Decision of Aisy Drink City of Bima." be accepted

\section{CONCLUSION}

The results of the research prove that the tastes of the Milky people are very high. This is evident from the effect of a greater taste on purchasing decisions when compared to prices. The people of bima, prioritizing good taste in buying, want its low price or even the price is expensive.

\section{REFERENCES}

Amirullah. (2013). Management research methodology. Malang: Bayumedia.

Ghozali, Imam. (2011). Aplikasi Analisis Multivariate Dengan Program SPSS. Semarang: Badan Penerbit Universitas Diponegoro.

Ghozali, Imam. (2013). Aplikasi Analisis Multivariate dengan Program IBM SPSS 21 Update PLS Regresi. Semarang: Badan Penerbit Universitas Diponegoro.

Haryanti, Intisari \& Nurdin, Herry. (2019). Fashion Trends and Hedonic Lifestyle on Decisions Purchase of Hijab Dresses in Bima. Li Falah-Jurnal Studi Ekonomi Dan Bisnis Islam, 4(2), 163-174, P-ISSN: 2541-6545, EISSN: 2549-6085.

Kotler, P \& Armstrong, Gary. (2011). Revised edition of marketing management. Jakarta: Erlangga

Kotler, Phillip \& Keller, Kevin Lane. (2009). Marketing Management. Issue 13. Volume 1. Translation by Bob Sabran 2008. Jakarta. Erlangga

Mutoharoh, Hasiolan, L. B \& Minarsih, M. M. (2015). The effect of television advertising, product quality, and lifestyle on the decision to purchase "Dettol" health soap. Journal of management.

Njoto, Tommy Kurniawan. (2016). The influence of packaging design, taste, and variety of products on consumer earth purchasing decisions. Jurnal Performa Jurnal Manajemen and Start-Up Busines, 1(4).

Romdonah, Rinda. (2014). The Effect of Product Innovation, Price and Brand Image on the Purchase Decision of Honda Beat Motorcycles (Case Study on Consumer Pratama Honda Dealer Kurnia Kasih). Journal of Management.

Sari, D. Y. (2013). Effect of Service Quality, Company Reputation, 
Product Attributes, and Taste of Consumer Repurchase Interest. Scientific Articles of Student Research Results.

Sugiyono. (2016). Metode Penelitian Kuantitatif Kualitatif dan $R \& D$. Bandung: Alfabeta

Suharso \& Yudi, Sutarso. (2010). Marketing in Practice. Yogyakarta: Graha Science
Tjiptono, Fandy \& Chandra, Gregorius. (2012). Strategic Marketing. Yogyakarta: Andy Publisher. 